\title{
Currents and convergence The ACRL 12th National Conference wrap-up
}

\begin{abstract}
ttendees of the ACRL 12th National Aconference, "Currents and Convergence: Navigating the Rivers of Change," held in Minneapolis, April 7-10, 2005, had the opportunity to explore ideas, interact with colleagues and vendors, and share research results and success stories. The Minneapolis conference committee, chaired by Camila A. Alire, dean of library services, University of New Mexico, selected more than 300 stimulating and thought-provoking programs.

The committee's efforts were appreciated

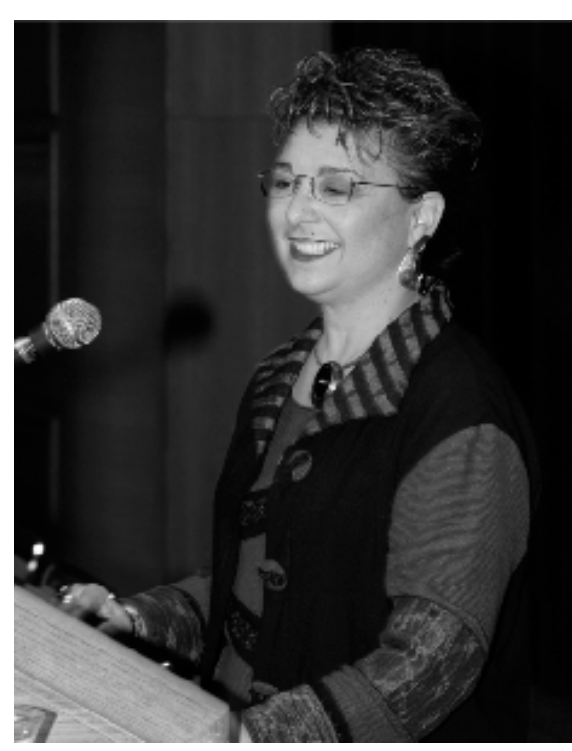

Camila Alire, ACRL 12th National Conference chair and incoming ACRL president, welcomes attendees to Minneapolis.
\end{abstract} by the 2,800 conference participants, which included 1,059 first-time attendees and 94 scholarship recipients. The conference drew nearly 4,000 total attendees (including paid registrants, exhibitors, staff, and guests), a record-breaking number.

\section{Keynotes and invited papers}

Keynote addresses and invited papers from outside the library field gave fresh perspectives and insights on areas of common interest, including library buildings, first-year students, and the diverse communities served by academic libraries. In his opening keynote, William Mitchell, professor of architecture and media arts and sciences at Massachusetts Institute of Technology, challenged the audience to view technology and the space it inhabits in a new way. He pointed out that wireless connectivity reduces the need to organize spaces around technical requirements, and he emphasized the new importance of "unassigned" space, where individuals and groups work and interact.

Invited paper presenter Betsy Barefoot, co-director of the Policy Center of the First Year of College at Brevard College in North Carolina, shared research and perspectives on first-year students. She emphasized that the first year is a time for students to establish patterns of behavior and hopefully chart successful pathways, both socially and academically. In applying her group's research to library instruction, Barefoot suggested librarians keep in mind that few students understand plagiarism, most benefit from peer mentors, and integrating library instruction into the curriculum seems to be a successful strategy.

"A Place to Belong: The Library as Prototype for Context Diversity" was the topic of a

Julia Kelly is reference librarian at the University of Minnesota-St. Paul, e-mail: jkelly@tc.umn.edu; Joan Roca is dean of library services at Minnesota State University-Mankato, e-mail: roca@mnsu.edu; and Ross Thrasher is director of library services at Mount Royal College in Canada, e-mail: rthrasher@mtroyal.ca

(c) 2005 Julia Kelly, Joan Roca, Ross Thrasher 


\section{Who are the wolves? A feral professional at the ACRL National Conference}

I am not a librarian, and yet I recently returned from my first ACRL National Conference in Minneapolis. I am an administrator charged with facilitating collaborations between 26 small private liberal arts colleges. I do this work for the Midwest Instructional Technology Center (MITC), one of three regional centers that make up the National Institute for Technology and Liberal Education (NITLE). At the core of our charge and our method is a belief that small, private liberal arts colleges must collaborate on considering questions of technology and teaching, and that such collaborations must be grounded in and informed by three perspectives: those of faculty, of instructional technologists, and of librarians.

I have a long history of working with librarians as teaching faculty and an IT professional, however, it was last summer's Frye Leadership Institute that taught me (among many other things) that I really needed to spend more time considering the library. The librarians among my Frye classmates made a unanimous suggestion: Come to the ACRL National Conference in Minneapolis. And they were right. From the first timers' session to the closing session, I was struck by the thoughtful and engaged presenters and by the fact that they were asking questions about collaboration, change, pedagogy, and technology that were the questions I, too, was asking.

The panel session, "Menage a Trois: The Essential Computing, Library and Instructional Technology Partnership to Advance New Media Learning," given by a group from Columbia University, made a particular impact. It gave a very positive look at collaboration between library, IT, and instructional technology. The panel stressed the value not only of substantive knowledge, but also of acknowledging the method of approach that each brings to the effort. Clearly this group was going about collaboration in a way that was sensitive to and drew upon the different perspectives of each of the groups, while keeping the pedagogical and disciplinary needs of the faculty at the center. I did find myself wishing they might have been able to bring one of those faculty members to join the panel.

Roberto Ibarra's invited paper "A Place to Belong: The Campus Library as Prototype for Context Diversity" suggested the limits of structural and multicultural approaches to diversity. Ibarra argued that the barriers to diversity lay more deeply in the origins of academic culture in a centuries-old German research model that displaces questions of, for instance, relationship, in favor of more abstracted, disembodied concepts and methods of learning. How might we be more effective at teaching if we stop trying to adjust the user to better use the library and toward adjusting the library to better meet the needs of users? I found myself asking what this might also suggest about furthering relations between the IT and library. Perhaps we need to find ways of attracting each other to our projects and organizations and to help each other thrive in them in ways that recognize the value of the contexts each of us brings to those efforts.

For me, James Neal's talk, "Raised by Wolves: The New Generation of Feral Professionals in the Academic Library," picked up where Ibarra's talk left off. What happens as you introduce professionals into libraries who do not share the socialization implied by the MLS degree? As I listened I found myself wondering who the "wolves" are who are "raising" these feral professionals? Most of these professionals do come with cultural traditions of their own, whether from IT or from academic disciplines, and thus do have "culture," even if it is different than that 
of the more traditional librarian. As such, the process of socialization may need to be conceived as a process of engaging in equal exchanges with these individuals as cultural representatives.

Sylvia Hurtado's closing keynote built upon the insights of cognitive psychology to note that, while our tendency is toward mindlessness to save our thinking for "important" things, we must create disequilibrium, both in ourselves, and in our students, to help break mindlessness and learn. Furthermore, the learning and development that takes place once we are in such situations of disequilibrium happen most effectively through social interaction.

This is what I experienced as a feral professional at the ACRL National Conference: having begun to settle into a (not quite) mindless comfort with my perspective from IT and faculty locations, it was unsettling to find myself immersed within the library discourse. Drawing upon the supportive environment and interaction with individual librarians, especially those I knew from Frye and from the institutions in the Associated Colleges of the Midwest and Great Lakes Colleges Association, I began to engage with this new perspective and to begin the process of incorporating it more fully into myself. Yet, I also hope that the opposite occurred, and that my attending and engaging with librarians has changed ACRL just a little as well.

I think we need more opportunities to put ourselves into unfamiliar situations, not to simply take on a fixed IT, library, or faculty perspective, but to engage with them, to learn and be changed by them and, in turn, to change them. Perhaps we can begin to ask how to attract each other to our organizations and how to help each other thrive within them.-Alex Wirth-Cauchon, wirth-cauchon@midwest-itc.org, Midwest Instructional Technology Center talk by Roberto Ibarra, a sociology professor at the University of New Mexico. He defined context diversity as a way to reframe rather than reform the academic community, and he observed that many libraries already focus on improving the environment for all learners.

\section{Conference themes: First-year experience and beyond}

A number of themes emerged among the hundreds of papers, panels, posters, and roundtables that made up the conference.

In addition to Barefoot's discussion of first-year students, a number of other sessions focused on the characteristics and learning styles of "millennials" or members of the "Net Genera-

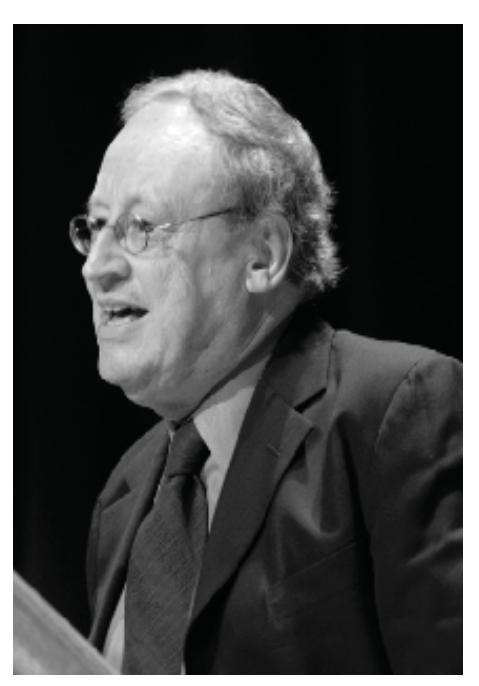

In his opening keynote address, William Mitchell of MIT applied anthropological analyses to discuss changes brought about by new communication and information technologies and what this means for libraries. tion" (students born between 1979 and 1994) and older, nontraditional students. A preconference on making libraries relevant to younger students featured a live focus group made up of millennials from the Twin Cities, while a paper by Kimberly Franklin (libraries of the Claremont Colleges) highlighted the perceptions of graduate students, especially in regard to information literacy.

Other sessions covered capturing the attention of millennials through marketing efforts and various instruction activities.

Presentations on space focused on the realities of building projects, revamping or eliminating the reference desk, sharing space with campus computing, and creating an information com- 
mons. During the panel session, "Keeping Baby: Cost Realities and Choices of What Can Be Thrown Out in Building Projects," five participants in a \$100 million library expansion at San Francisco State University discussed the planning and cost-control process. The workshop "Trading Spaces: Designing Instruction That Fits by Balancing Space, Technology, and Learning" explored how outdated design, limited space, and technological barriers can interfere with effective instruction.

\section{Learning about open access}

Scholarly communication was discussed from numerous viewpoints. In a panel highlighting the open-access models and federally funded research, the National Institutes of Health (NIH) Director Elias Zerhouni, via videotape, discussed the new NIH recommendations on making articles freely available within a short time after publication. Elizabeth Marincola, American Society for Cell Biology, discussed her group's policy of making articles public just two months after they appear in print and gave insights about the societies that choose not to participate as fully in the open-access movement. Another panel challenged attendees to envision a world where open access was the norm, and to consider how to prepare for that reality.

For anyone wondering about the rewards and hurdles involved in publishing an openaccess journal, faculty member Ken Carter and librarian Kitty McNeill (Emory University) discussed the details of their efforts to launch The Journal of Cognitive Affective Learning (www.jcal.emory.edu), a joint effort of the library and an academic department.

\section{ACRL's Virtual National Conference}

For the first time, ACRL offered a virtual conference to complement the faceto-face conference in Minneapolis. The ACRL Virtual National Conference was held completely via the Internet and included select 12th National Conference speakers in live, interactive Webcasts. Virtual attendees were able to keep up with the pulse of the conference via daily blogs and conference images from roving "conference correspondents."

The virtual conference online community will remain available to both virtual and face-to-face conference attendees through April 2006. In addition to archives of Webcasts held in April, the online community also includes text-based discussion boards so participants can chat about hot conference issues. Log in to join the conversation; discussion threads include:

- Assessment without action

- Exploring portals: Portal OR NOT to portal, Is that still a question?
- Googlelizors and Resistors: Which one are you?

- Librarians and the first-year experience

- Obstacles for Institutional Repositories

You can also view speaker materials, such as PowerPoints, bibliographies, speaker bios, and texts of invited and contributed papers. The community can be accessed at home.learningtimes.net/acrl.

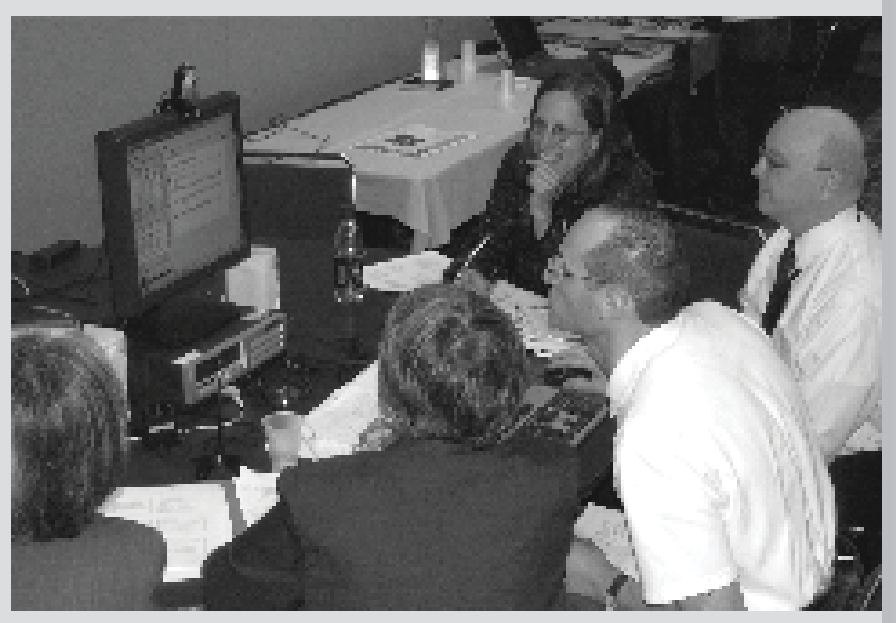

Presenters from six panel presentations reconvened to produce live, interactive Webcasts for the virtual conference audience. 


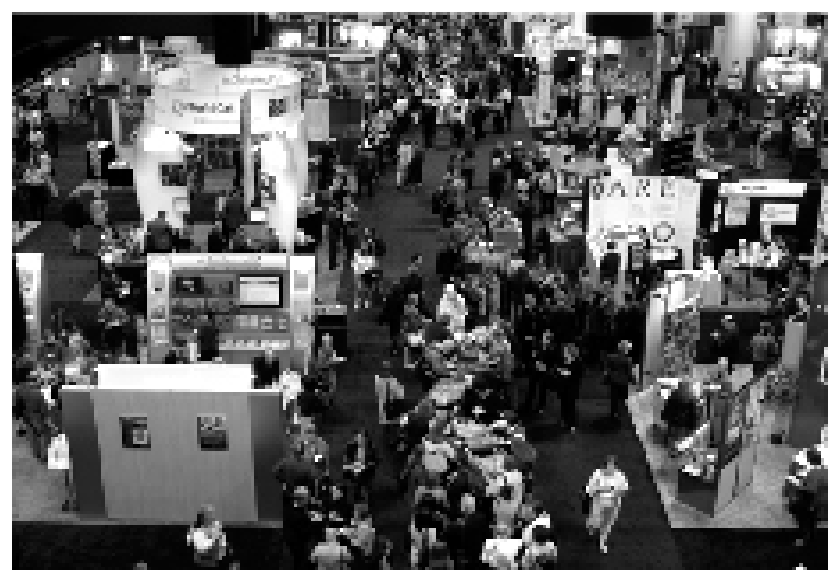

Conference attendees flocked to the exhibits during the opening reception and throughout the conference.

and carrying out activities for students. One panel focused on working with first-year students, and in the paper, "Improving Instruction: What Librarians Can Learn from the Study of College Teaching," Scott Walter (University of Kansas) linked the ideas about college teaching to opportunities for librarians to become better teachers. Papers on curiosity, motivation, and using the Socratic method challenged listeners to look at their work as instructors in new ways. During the preconference workshop "Information Literacy in the

\section{The Google effect}

Google Scholar and Google Print were highlighted in a session with Adam Smith, Google product manager, and John Price Wilkin from the University of Michigan-one of the institutions partnering in the Google Print digitization effort. They addressed expectations, challenges, and possible future scenarios.

Google was also the topic of a number of papers and posters that addressed how librarians teach about it, what students know about it, and how it has impacted the information landscape. The panel session "Googlelization, Visualization, Metasearch, Mapping and Other Disruptive Technologies: Implications of Revolutionary Change for User Education and Information Literacy" began with an entertaining debate as to whether library catalogs and search screens should emulate the Google interface. The "pro" side argued that Google is a good model because it offers simple and advanced searching, and because it is fast and wideranging; while the "cons" cited inefficient and nonauthoritative results and a lack of precision and comprehensiveness.

\section{Information literacy and the role of reference}

The conference was rich in opportunities to learn more about information literacy. Posters and roundtables addressed the practical aspects, with many examples of successful strategies for engaging faculty members
Disciplines: Librarian/Faculty Collaboration for 21st Century Research," one of the speakers challenged librarians to adopt the point of view of providing a solution to a need and helping faculty accomplish what they want to achieve.

The changing role of reference and the expanding role of outreach were addressed in a number of sessions. Successful models for virtual reference were debated, and a

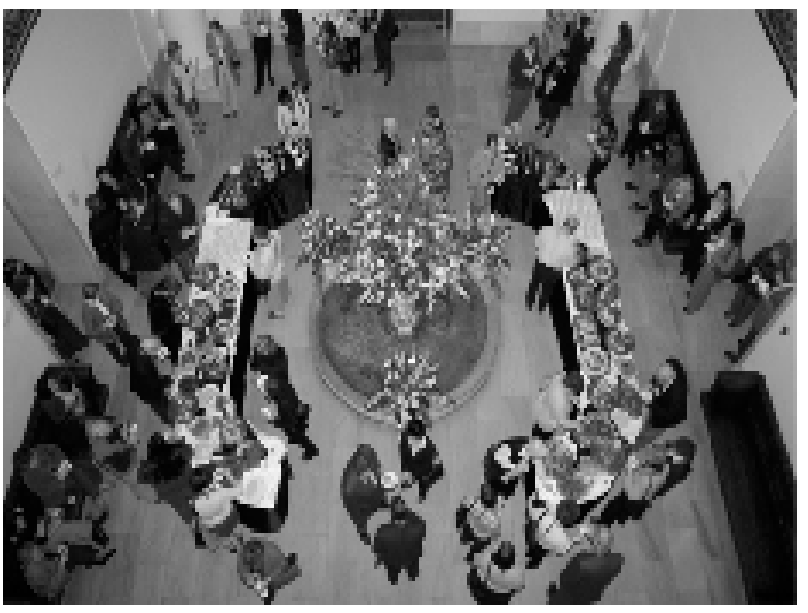

The All-Conference Reception was held on Saturday night at the Minneapolis Institutes of Arts, offering a chance to mingle with colleagues, soak in some culture, and enjoy fantastic desserts.

panel from Portland State University looked back on the predictions about changes in reference service to see if the "rethinking reference" challenges have been addressed. Groups reported about closing their reference desk, relocating it outside, staffing it completely with students, and sharing the desk with computer support personnel. In the 


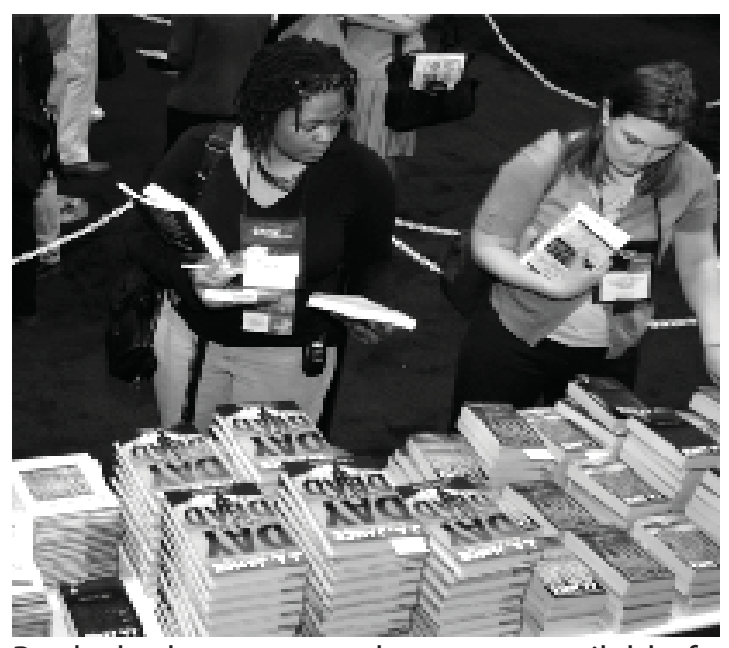

Books by keynote speakers were available for sale in the ACRL/Bound to be Read Bookstore, a real plus for attendees heading for the book signings.

panel "Academic Libraries Reap Benefits From Community Outreach," presenters described ways that campus libraries, in collaboration with student groups, could use ALA traveling exhibits as a starting point for community programming.

\section{Managing collections and preserving knowledge}

Digital archives, institutional repositories, and other forms of electronic preservation were also featured, with a preconference devoted to institutional repositories and a workshop on institutional repositories for smaller libraries. Several posters touched on the topic, and one paper covered the Western Waters Digital Library, which is a collaborative effort of several academic libraries.

Collection topics at the conference included a reality check on cooperative col-

\section{Miss a session?}

Audiorecordings of ACRL National Conference sessions are available for purchase at www.cmc-net.com/ (click on the ACRL logo). You can also order the 12th National Conference Proceedings online at www.acrl.org/publications. lection development and a look at collecting zines in an academic library. The challenges of doing collections work in an electronic world were addressed by several speakers, and one panel focused on the ever-evolving jobs of electronic resource librarians.

A session on knowledge biodiversity explored the atomization of news and its impact on the preservation of knowledge in popular news publications as distributed in various formats. Identifying the pitfalls of relying on commercial interests to capture and preserve "heritage" information, the presenter challenged librarians to address such issues as 1) technology and the methodical selection and archiving of information, 2) political interest when it is not in the best interest of the organizations in power to preserve such information and/or the lack of incentive to do so, and 3) the lack of compelling economic

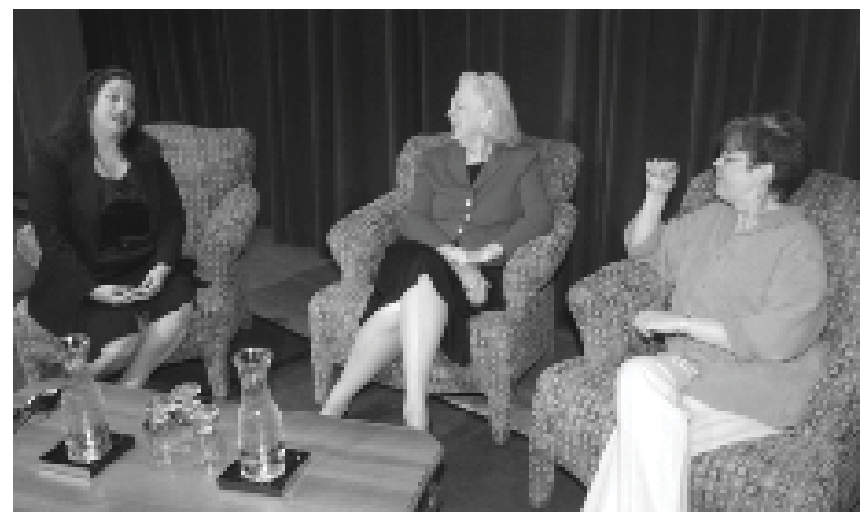

Mystery writers Carolina Garcia-Aguilera (left), J. A. Jance (center), and Valerie Wilson Wesley (not pictured) discussed their works with moderator Liane Hansen (right) of National Public Radio during Saturday's keynote luncheon. reasons to invest in such an enterprise given market forces.

Successful methods for collaborating with faculty members were highlighted in a number of talks, as academic librarians spend more time working closely with departments and less time at the reference desk.

Other topics that were represented during the conference include:

- Blogs, portals, and other new technologies, which were popular in discussions at roundtables 
- Geographic information systems, with several posters devoted to the practical aspects of the library's involvement in campuswide efforts

- Copyright issues, especially in the electronic environment

- Federated searching, with its challenges and rewards

- Theater skills for librarians, covered in a half-day workshop

- Assessment and surveys, such as LibQual, which help librarians create usercentered services

- Practical statistics for librarians, which was a popular workshop

- Promotion and marketing efforts, especially for instruction and consultation services

- Distance students-who is serving them, and is it effective?

- Peer tutoring in the library

- Mentoring of new librarians

Many librarians love a good mystery, and their appetites were satisfied at the Key- note Luncheon, which featured a group interview with mystery writers Caroline Garcia-Aguilera, J. A. Jance, and Valerie Wilson Wesley. Liane Hansen, National Public Radio, moderated a lively discussion. The authors shared the paths that led them to write mysteries (Garcia-Aguilera has worked for many years as a private investigator), how their stories unfold, and other secrets of the trade.

With close to 2,800 participants from all 50 states and 15 countries, more than 300 total sessions to choose from, and a large and diverse selection of vendors in the exhibit hall, it's no mystery why this year's conference was a resounding success. $z$

\section{Conference reports available online}

More detailed reports of select programs from the ACRL 12th National Conference are available in the online article.

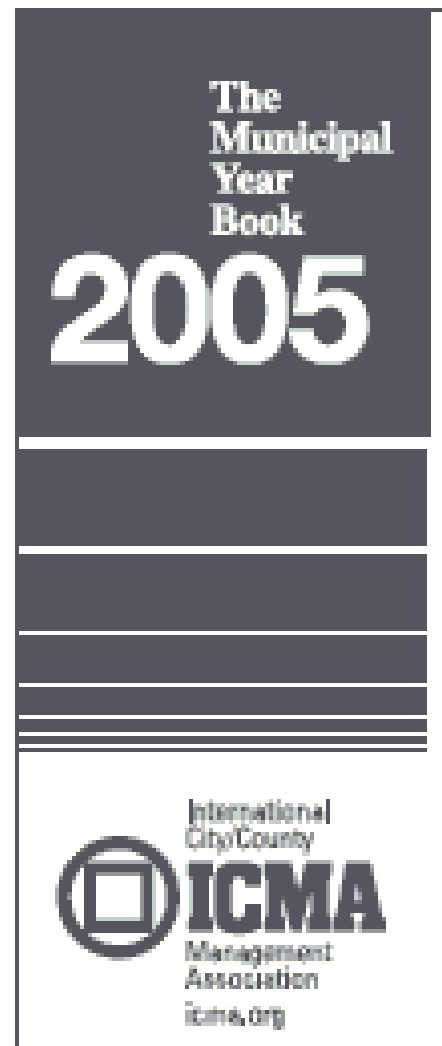

\section{The definitive resource for local government trends and data}

\section{Find the answers to the questions you are asked every day about local government.. .}

- coping with budget crises

- contracting out

- e-governiment

- approaches to active living

- rimenting govemment

- statistics, projections, management trends, and much more.

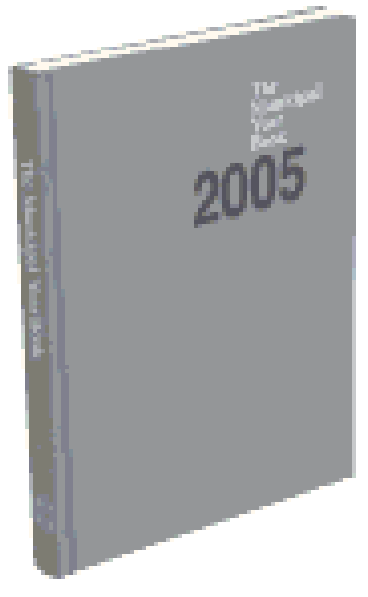

Mos $245+$ P. handorar trem $\$ 4$ sose 